\title{
Deleneation of groundwater quality in the presence of fluoride in selected villages of Simlapal block, Bankura district, West Bengal, India
}

\author{
Kousik Das $^{1}$ (1) $\cdot{\text { Uttiya } \text { Dey }^{2} \cdot \text { Naba Kumar Mondal }}^{2}$
}

Received: 6 October 2015/Accepted: 9 September 2016/Published online: 21 September 2016

(C) Springer International Publishing Switzerland 2016

\begin{abstract}
Fluoride contamination and other physicochemical parameters in groundwater of Simlapal block of Bankura district were investigated. A total of 50 deep tube well (DTW) samples were collected from 18 villages of Simlapal. The higher concentration of iron values was recorded, $9.40 \mathrm{mg} / \mathrm{L}$ with an average value of $2.11 \mathrm{mg} / \mathrm{L}$. Drastically, $58 \%$ of water samples exceed the permissible limit of $1.5 \mathrm{mg} / \mathrm{L}$ (Guidelines for drinking water quality, World Health Organization, Geneva, 2004). Spatial distribution of $\mathrm{F}^{-}$(Guidelines for drinking water quality, World Health Organization, Geneva, 2004) concentration classes is represented by the simple Inverse Distance Weighting (IDW) interpolation method. The affinity between the $\mathrm{pH}$ and $\mathrm{F}^{-}$in groundwater suggests the dissolution of fluoridebearing minerals in groundwater. Furthermore, the $\mathrm{pH}$ has a good positive correlation with $\mathrm{HCO}_{3}{ }^{-}(r=0.224)$. This indicates a prevailing condition of alkalinity (caused by $\mathrm{HCO}_{3}$ only here) in the groundwater, which promotes a mineral dissolution. The $\mathrm{F}^{-}$shows a significant positive correlation with $\mathrm{pH}(r=0.313, p<0.05)$ and $\mathrm{HCO}_{3}{ }^{-}$ $(r=0.224)$, while it has a negative correlation with $\mathrm{Ca}$ and $\mathrm{Mg}$ ions $(r=-0.225$ and -0.226$)$. PCA accounts for $74.21 \%$ of the variability for the first four components. F1 values have high loading (32.71\%), second component (F2) exhibits $19.98 \%$, third component (F3) shows $12.74 \%$, and fourth component (F4) shows only $8.72 \%$ of the total variability to justify the significant correlation
\end{abstract}

Kousik Das

kousik.envs@gmail.com

1 School of Environmental Science and Engineering, Indian Institute of Technology Kharagpur, Kharagpur, WB, India

2 Department of Environmental Science, The University of Burdwan, Burdwan, WB, India between chemical constituents. In terms of quality of water, sodium adsorption rate (SAR) showed that all the samples are from the group of excellent to good. With respect to permeability, sodium percentages show that $18 \%$ are permissible but doubtful and $2 \%$ are unsuitable for irrigation purposes.

Keywords Fluoride $\cdot$ Salinity $\cdot$ Bankura $\cdot$ Hydrology IDW $\cdot$ Water contamination $\cdot$ Geo-stat

\section{Introduction}

Groundwater quality problems have emerged in many geographical areas owing to natural environmental calamities and anthropogenic interferences in the ecosystems. Groundwater resources, in many instances, supplement surface water, particularly as a source of drinking water. Chemical composition of groundwater in correspondence with water quality is a function of dependent factors, including precipitation composition, mineralogy of aquifer as well as geochemical process, such as oxidation reduction reaction. The anomaly which occurs in groundwater by altering chemical and physical properties from minerals can have profound effects on groundwater quality and aesthetic value (Rajmohan and Elango 2004).

Fresh water resource is becoming scarcer day-by-day due to faster rate of deterioration of the water quality. The suitability of groundwater for irrigation as well as domestic and industrial purposes depends upon its quality. A variety of activities are polluting these valuable resources. Fluoride is one of the major concern in groundwater quality.

Groundwater contamination by fluoride was emerging as one of the global problem, including India (Das and Mondal 2016; Karthikeyan et al. 2010). Fluoride is the 
lightest member of the halogen group of elements. In a number of respects, its behavior is quite different from other halogens and this is reflected in natural water also.

The natural concentration of fluoride depends on the geological, chemical, and physical characteristics of the aquifer (Meenakshi et al. 2004). Fluorine is a lithophile element with atmophile affinities, and occurs in many common rock-forming minerals viz., fluorapatite $\left[\mathrm{Ca}_{5}(-\right.$ $\left.\mathrm{PO}_{4}\right)_{3} \mathrm{~F}$, cryolite, apatite, fluorospar $\left(\mathrm{CaF}_{2}\right)$, and hydroxylapatite (Farooqi et al. 2007). High fluoride concentration may be found in groundwater especially in areas with volcanic rocks (Tekle-Haimanot et al. 2006). Therefore, high $\mathrm{F}^{-}$ concentrations in groundwater are expected in areas, where fluoride-bearing minerals are abundant in the geologic substrate (Samal et al. 2015; Chakrabarti and Bhattacharya 2013; Shaji et al. 2007; Thirumalesh et al. 2011). Fluoridebearing well waters tend to be high in sodium and bicarbonate alkalinity and low in calcium hardness. High fluoride containing groundwater is chemically distinctive in that it is soft, has high $\mathrm{pH}$, and contains large amount of silica.

Fluoride $\left(\mathrm{F}^{-}\right)$is an essential micronutrient for human beings, serving to strengthen the apatite matrix of skeletal tissues and teeth (Maithani et al. 1998). On the other hand, due to excessive fluoride intake, tooth enamel loses its luster. Besides skeletal and dental fluorosis, excessive consumption of fluoride may lead to muscle fiber degeneration, low hemoglobin levels, excessive thirst, headache, skin rashes, nervousness, depression, etc. (Ayoob and Gupta 2006).

In the present study, a survey of groundwater at fluoride affected areas of Simlapal block of Bankura district was carried out during 2012 to investigate the level $\mathrm{F}^{-}$and other water quality parameters (temperature, $\mathrm{pH}, \mathrm{EC}$, TDS, alkalinity, $\mathrm{Na}^{+}, \mathrm{K}^{+}, \mathrm{Ca}^{2+}, \mathrm{Mg}^{2+}, \mathrm{Cl}^{-}, \mathrm{SiO}_{2}, \mathrm{HCO}_{3}^{-}$, $\mathrm{CO}_{3}{ }^{2-}, \mathrm{Fe}^{2+}, \mathrm{SO}_{4}{ }^{2-}$, and $\mathrm{PO}_{4}{ }^{-}$), to assess their potential relationship with $\mathrm{F}^{-}$. In the present study, a large data set obtained during 2012 was subjected to different multivariate statistical techniques (PCA) to extract information about the similarities or dissimilarities between sampling sites and identification of water quality variables responsible for groundwater contamination. Sodium absorption ratio and saturation index of water sample of each site were also computed to check the suitability of groundwater for irrigation purpose.

\section{Materials and methods}

\section{Study area}

The district is divided into three distinct topographical regions, viz., the hilly terrain in the western part, undulating central part, and alluvial plain in the eastern part, where the study was conducted. The study examined 18 selected villages of Simlapal block of Bankura district, West Bengal, India (Fig. 1). Geographically, the study area extended from $22^{\circ} 54^{\prime} 00^{\prime \prime} \mathrm{N}$ and $87^{\circ} 00^{\prime} 00^{\prime \prime} \mathrm{E}$ to $22^{\circ} 59^{\prime} 00^{\prime \prime} \mathrm{N}$ and $87^{\circ} 30^{\prime} 00^{\prime \prime} \mathrm{E}$. The district of Bankura is known as drought prone, and dry season water for drinking and other uses is a major problem for this area. A majority of the shallow wells go dry or retain scant water, or dry up during winter and summer. The water level varies in the district from 1.5 to $22 \mathrm{~m}$. Artesian flows are generally obtained from aquifers occurring between the depth span of 30-75 m. Thus, most of the tube wells are installed in this respective area at deeper depth, and all the deep tube wells (DTW) are considered in this present study.

\section{Climatology}

Though the district receives average annual rainfall of $1400 \mathrm{~mm}$ in a year, $80 \%$ of the total rainfall is received during 4 months of the year. Groundwater in the district occurs both under water-table condition and confined condition. Groundwater in the near surface aquifers occur under water-table condition, and in deep aquifers under confined or sub-artesian condition in favorable terrain. The primary source of groundwater is rainfall, a part of which is lost as evaporation, and transpiration and another part move as surface run-off and the remaining part percolates into the ground from direct rainfall or by lateral infiltration from surface waterbodies to form saturated groundwater zone.

\section{Geology and soil type}

The Bankura district is mainly a hard rock terrain. Here, crystalline basement occurs at very shallow depth. The district is geomorphologically divisible into three prominent north-south trending zones viz, the hilly hard rock dominated tract on the west (hard rock province), the sedimentary plain lands on the east (alluvial province), and the undulating tract with occurrence of both rocky and alluvial formations on the central part (mixed formation province). However, the respective covered study area mostly contains laterite and a lesser portion of Jirabaid village consists of phyllite mica schist (Source: NBSS/LUP 2016). Study area is mainly consists of seven types of soil textural classes (Fine soil, fine loamy sandy soil, fine loamy moderate soil, coarse loamy soil, loamy soil, and fine loamy deep soil) (Fig. 1).

\section{Sample collection and analysis}

Samples were randomly chosen from the 50 DTW of Simlapal block of Bankura district, but exact depth of each 

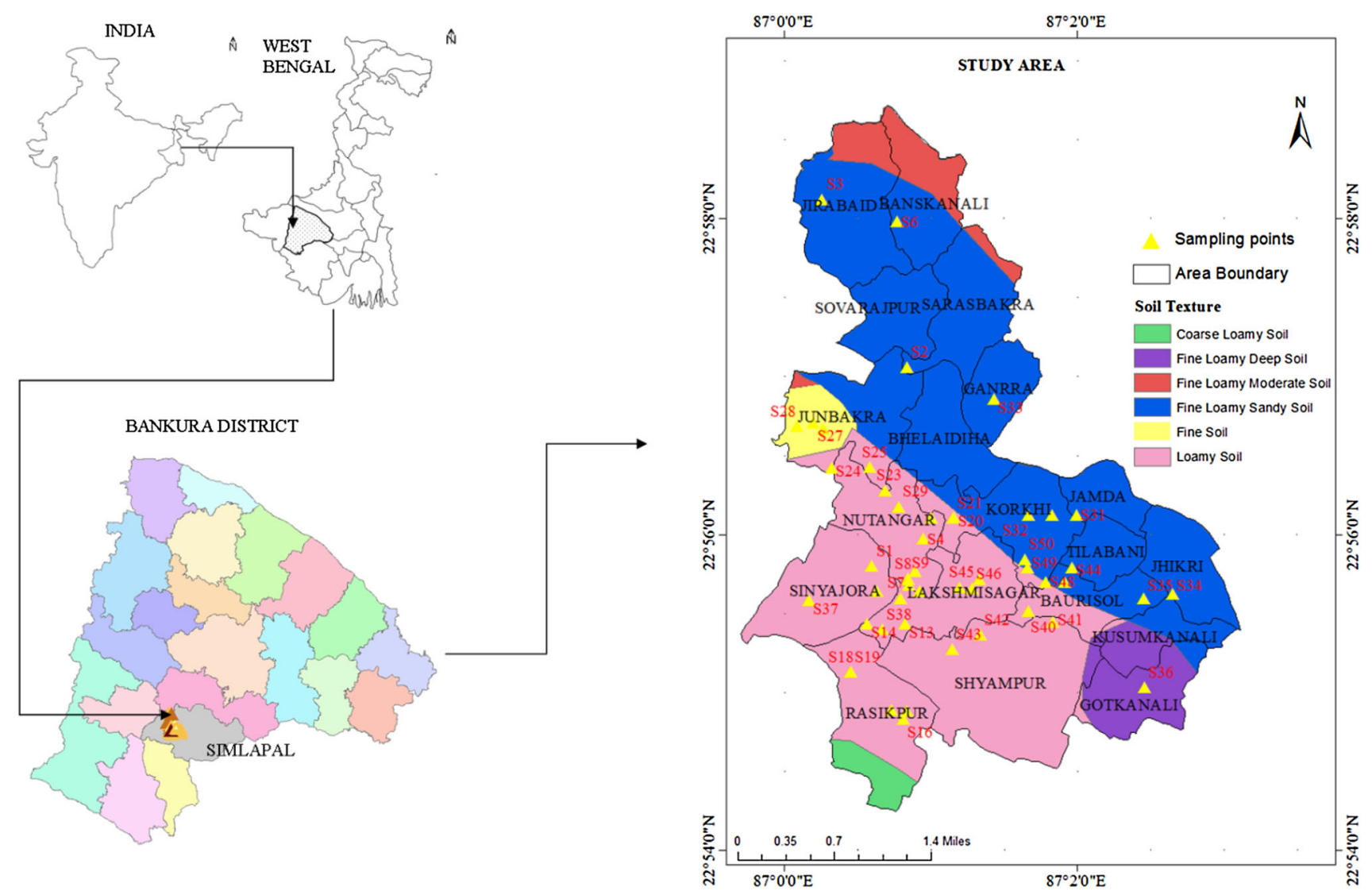

Fig. 1 Geographical representation of study area along with sampling location (S1-S50 represents the sample number) and respective soil textural classification

of the tube well is unknown (Fig. 1; Table 1). Few of the tube wells are privately owned and installed, and the rest are installed by the Public Health Engineering Department (PHED, GoWB). All the samples were collected in $300 \mathrm{ml}$ sterilized polypropylene (Tarson made) bottles and stored in freezing condition (temperature $<10{ }^{\circ} \mathrm{C}$ ), by following the standard protocols. Geographical positions of all the sampling sites are recorded during the sampling using GPS (Model: GARMIN GPS 12). Study area map with sampling location points and post map with fluoride distribution were constructed using ArcGIS 10.2.1.

Different water quality parameters, their units, abbreviations, and methods of the analysis applied in triplicate manner on each composite samples of water are summarized in Table 2. In the field, $\mathrm{pH}$ and electrical conductivity (EC) were measured by PCSTestr 35 (EUTECH), and the rest of the parameters were measured $\left(\mathrm{Na}^{+}, \mathrm{K}^{+}, \mathrm{Ca}^{2+}\right.$, $\mathrm{Mg}^{2+}, \mathrm{Cl}^{-}, \mathrm{SO}_{4}{ }^{2-}, \mathrm{HCO}_{3}{ }^{-}, \mathrm{CO}_{3}{ }^{2-}, \mathrm{Fe}^{2+}, \mathrm{SiO}_{2}$, and TDS) by following the standard method of APHA (1998) 20th edition after being kept in the laboratory.

Fluoride content in groundwater was measured using ion selective electrode (model: Thermo Scientific Orion 4-Star). During the measurement, ionic strength of fluoride was adjusted by buffer (TISAB III), and concentration of fluoride was estimated in comparison with the standard known fluoride solutions. The accuracy of the chemical analysis was verified by calculating charge balance errors (viz, cationic and anionic charge balance), and it was found that the errors were below $\pm 5 \%$, an added proof of precision of analytical data.

\section{Quality control assurance}

All chemicals and reagents of EDTA, nitric acid, hydrogen peroxide, sulfuric acid, hydrochloric acid, sodium carbonate, potassium hydroxide, sodium hydroxide, and sodium hydrogen carbonate were of analytical grade, Merck (Darmstadt, Germany).

Quality control measures were taken to assess the contamination and reliability of the analyzed data. For quality control purposes, care was taken for sample collection and preservation during every experimental procedure. For analytical precision, each (water and sediments) analysis was performed for three replicate samples. Double distilled deionized water was used throughout the experiment. Glassware was properly cleaned, and E-mark (AR grade) 
Table 1 Sample number along with their source and habitation/village

\begin{tabular}{|c|c|c|c|c|c|c|}
\hline Block & Panchayet & Habitation/village & Source & No. of sample & Sample no. & $\mathrm{F}^{-}$avg. $(\mathrm{mg} / \mathrm{L})$ \\
\hline Simlapal & Laxmisagar & Banskanali & Deep tube well & 1 & S6 & 4.90 \\
\hline Simlapal & Laxmisagar & Baurisol & Deep tube well & 3 & $\mathrm{~S} 35, \mathrm{~S} 40, \mathrm{~S} 47$ & 1.25 \\
\hline Simlapal & Laxmisagar & Bhelaidiha & Deep tube well & - & - & - \\
\hline Simlapal & Laxmisagar & Ganrra & Deep tube well & 1 & S33 & 0.86 \\
\hline Simlapal & Laxmisagar & Gotkanali & Deep tube well & 1 & S36 & 1.50 \\
\hline Simlapal & Laxmisagar & Jamda & Deep tube well & 1 & S31 & 0.72 \\
\hline Simlapal & Laxmisagar & Jhikri & Deep tube well & 1 & S34 & 0.88 \\
\hline Simlapal & Laxmisagar & Jirabaid & Deep tube well & 1 & S3 & 2.10 \\
\hline Simlapal & Laxmisagar & Junbakra & Deep tube well & 6 & $\mathrm{~S} 23, \mathrm{~S} 24, \mathrm{~S} 25, \mathrm{~S} 26, \mathrm{~S} 27, \mathrm{~S} 28$ & 3.10 \\
\hline Simlapal & Laxmisagar & Korkhi & Deep tube well & 7 & S20, S21, S30, S32, S48, S49, S50 & 1.81 \\
\hline Simlapal & Laxmisagar & Kusumkanali & Deep tube well & - & - & - \\
\hline Simlapal & Laxmisagar & Lakshmisagar & Deep tube well & 7 & S11, S13, S14, S38, S45, S46, S39 & 2.94 \\
\hline Simlapal & Laxmisagar & Nutangar & Deep tube well & 8 & $\mathrm{~S} 4, \mathrm{~S} 7, \mathrm{~S} 8, \mathrm{~S} 9, \mathrm{~S} 10, \mathrm{~S} 12, \mathrm{~S} 22, \mathrm{~S} 29$ & 2.50 \\
\hline Simlapal & Laxmisagar & Rasikpur & Deep tube well & 5 & S15, S16, S17, S18, S19 & 1.37 \\
\hline Simlapal & Laxmisagar & Sarasbakra & Deep tube well & 1 & $\mathrm{~S} 2$ & 2.60 \\
\hline Simlapal & Laxmisagar & Shyampur & Deep tube well & 3 & S41, S42, S43 & 0.79 \\
\hline Simlapal & Laxmisagar & Sinyajora & Deep tube well & 3 & S1, S5, S37 & 1.82 \\
\hline Simlapal & Laxmisagar & Sovarajpur & Deep tube well & - & - & - \\
\hline Simlapal & Laxmisagar & Tilabani & Deep tube well & 1 & $\mathrm{~S} 44$ & 0.99 \\
\hline
\end{tabular}

Habitation/village with only one sample represents the $\mathrm{F}^{-}$concentration of that sample rather its average

-Unavailability of sample

standards were used for the preparation of the standard curve during analysis of samples. For further enhancement of the experimental results, the mean values for each parameter along with standard deviation (SD) and coefficient of variance $(\mathrm{CV})$ were considered.

\section{Statistical analysis}

All mathematical and statistical computations were made using the XLSTAT-Pro v7.5.2 and Minitab 2016 software. Multivariate statistical methods for classification, modeling, and interpretation of large data sets from environmental monitoring programs allow the reduction of the dimensionality of the data and the extraction of information that will be helpful for the water quality assessment (Liu et al. 2003). The basic statistics and correlation calculations were carried out to give the initial information about the water quality data. Unless otherwise indicated, the characteristics of the cases were described as mean, minimum value, maximum value, $95 \%$ confidence intervals of the mean value, and standard deviation (SD).

\section{Spatial distribution of ions}

All the data were incorporated into a spatial database, and spatial variations of the results were developed using the inverse distance weighting (IDW) method. The ArcGIS software (version 10.2.1) was used for developing maps. IDW interpolation assumes that each measured point has a local influence that diminishes with distance. Thus, points in the near neighborhood are given high weights, whereas points at a far distance are given small weights.

\section{Result and discussion}

The experimental data indicated that the wide variations in the level of all physicochemical parameters, including $\mathrm{F}^{-}$ concentration in the groundwater, may be due to the geochemical intervention of the affected study area. Hydro chemical data of all the experimental samples are summarized in Table 2. Total hardness $(\mathrm{TH})$ of the groundwater samples ranges from 18.00 to $958.00 \mathrm{mg} / \mathrm{L}$ with an average value of $205.12 \mathrm{mg} / \mathrm{L}$. The groundwater in the study area could generally be classified from soft to hard. It was found that $40 \%$ of the samples are classified as hard water (Table 3). Groundwater of respective villages was found to be alkaline by $\mathrm{pH}$ values ranging from 7.32 to 8.13 within the desirable range for drinking purpose prescribed by WHO (2004). The total dissolved solid (TDS) of the groundwater samples in that area ranges from 31 to $987 \mathrm{mg} / \mathrm{L}$ with an average value of $380.95 \mathrm{mg} / \mathrm{L} .72 \%$ of water samples are found to be fresh, while only $28 \%$ are permissible for drinking irrespective of TDS presence 


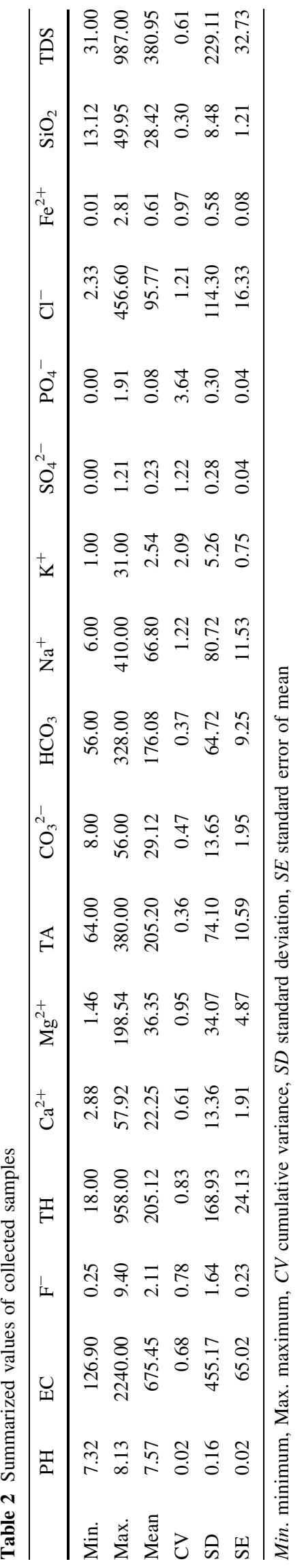

(Table 4). Electrical conductivity (EC) was measured by means of salinity of water. Values varied from 126.90 to $2240 \mu \mathrm{S} / \mathrm{cm}$, with an average of $675.45 \mu \mathrm{S} / \mathrm{cm}$. The high EC due to elevated TDS level indicates that the aquifer has been subjected to high salinity and soluble electrolytes in groundwater samples (Kaz et al. 2009).

Potassium and sodium among major cations show maximum variability $(\mathrm{CV}=2.09$ and 1.22$)$, where as $\mathrm{PO}_{4}{ }^{-}$and $\mathrm{SO}_{4}{ }^{2-}$ show maximum variability followed by $\mathrm{Cl}^{-}(\mathrm{CV}=3.64,1.22$ and 1.21). The abundance of major cations is $\mathrm{Na}^{+}>\mathrm{Mg}^{2+}>\mathrm{Ca}^{2+}>\mathrm{K}^{+}$, and the order of major anions is $\mathrm{HCO}_{3}{ }^{-}>\mathrm{Cl}^{-}>\mathrm{CO}_{3}{ }^{2-}>\mathrm{SO}_{4}{ }^{2-}$. Twelve percent of samples (S20, S26, S29, S40, S41, and S47) are exceeding permissible limit of $\mathrm{Cl}^{-}$according to WHO (2004). The higher concentration of $\mathrm{Cl}^{-}$in groundwater resources is generally taken as an index of impurity of groundwater (Laluraj et al. 2005). Eventually abundance of $\mathrm{Na}$ compared to $\mathrm{Ca}$ in water samples is the result of cation exchange processes (Girish 2013). $\mathrm{F}^{-}$is present in the groundwater in the range of $0.25-9.40 \mathrm{mg} / \mathrm{L}$ with an average value of $2.11 \mathrm{mg} / \mathrm{L} ; 58 \%$ of water samples exceed the permissible limit of $1.5 \mathrm{mg} / \mathrm{L}$ (WHO 2004).

The EC and TDS are significantly correlated with cations and anions in the studied groundwater samples which might be the consequence of ion exchange in aquifers. Major anions and cations are expressing/found to be highly correlated with each other at $95 \%$ confidence level. The highest correlation was found between $\mathrm{Na}$ with $\mathrm{HCO}_{3}{ }^{-}, \mathrm{CO}_{3}{ }^{2-}, \mathrm{Cl}^{-}$, and $\mathrm{SO}_{4}{ }^{2-}$ at $0.001 \%$ level, which was the affinity between proportional but opposite charges. Other ions $\left(\mathrm{Ca}^{2+}, \mathrm{Mg}^{2+}, \mathrm{PO}_{4}^{-}, \mathrm{SO}_{4}{ }^{2-}\right.$, and $\left.\mathrm{CO}_{3}{ }^{2-}\right)$ showed their competitive relationship at different levels of magnitude with opposite ions. A non-competitive relationship between the same charges and the same value number was observed in combination of $\mathrm{HCO}_{3}{ }^{-}, \mathrm{Cl}^{-}, \mathrm{K}^{+}$, and $\mathrm{Ca}^{2+}$.

The statistical study of interrelationship between $\mathrm{F}^{-}$and EC showed a negative relationship. However, the correlation coefficient is lower $(r=-0.038)$ (Table 5). Among the studied water samples, $58 \%$ are exceeding permissible limit of $\mathrm{F}^{-}$(WHO 2004) and showed negative relationship with $\mathrm{Ca}^{2+}$ and $\mathrm{Mg}^{2+}$ ions (Figs. 2, 3). The correlation coefficient value was found to be lower $(r=-0.225$ and -0.226) with $\mathrm{Ca}^{2+}$ and $\mathrm{Mg}^{2+}$ (Table 5). The inverse relationship between $\mathrm{F}^{-}$with $\mathrm{Ca}$ and $\mathrm{Mg}^{2+}$ was represented through bivariate scatter plots (Figs. 2, 3). However, the recommended limit of $\mathrm{F}^{-}$in the water depends on the climatic conditions of an area (USPHS 1987), because the amount of water consumed and the amount of $\mathrm{F}^{-}$ingested is influenced primarily by air temperature. For assessing the factors that control the $\mathrm{F}^{-}$content in the groundwater, understanding the influences of climate, slope, soil cover, lithology, anthropogenic activity, and marine source on 
Table 3 Distribution of samples according to TH concentration

\begin{tabular}{llll}
\hline TH & Description & Sample number & $\%$ of samples \\
\hline $0-60$ & Soft & S5, S14, S18, S19, S34, S36, S37 & 14 \\
$61-120$ & Moderately hard & S2, S3, S6, S11, S23, S28, S38, S42, S46, S48, S50 & 28 \\
$121-180$ & Hard & S9, S12, S13, S15, S21, S22, S24, S27, S32, S33, S35, S43 & 24 \\
$>180$ & Very hard & S1, S4, S7, S8, S10, S16, S17, S20, S25, S26, S29, S30, S31, S39, & 40 \\
& & S40, S41, S44, S45, S47, S49 & \\
\hline
\end{tabular}

TH total hardness

Table 4 Distribution of samples according to TDS concentration

\begin{tabular}{|c|c|c|c|}
\hline TDS & Description & Sample number & $\%$ of samples \\
\hline$<500$ & Fresh water/desirable for drinking & $\begin{array}{l}\text { S2, S3, S5, S6, S9, S11, S12, S13, S14, S15, S16, } \\
\text { S17, S18, S19, S20, S22, S23, S26, S27, S28, S31, } \\
\text { S32, S33, S34, S35, S36, S37, S38, S40, S41, S42, } \\
\text { S43, S45, S46, S48, S50 }\end{array}$ & 72 \\
\hline $500-1000$ & Brackish water/permissible for drinking & $\begin{array}{l}\text { S1, S4, S7, S8, S10, S21, S24, S25, S29, S30, S39, } \\
\text { S44, S47, S49 }\end{array}$ & 28 \\
\hline $1000-3000$ & Saline water/useful for irrigation & - & - \\
\hline$>3000$ & Brine water/unfit for irrigation and drinking & - & - \\
\hline
\end{tabular}

spatial distribution of $\mathrm{F}^{-}$is very essential. Figure 4 shows the spatial distribution of $\mathrm{F}^{-}$content in the study area.

A higher $\mathrm{Na}^{+}$indicates the dissolution of minerals and/ or soil salts as well as the influence of anthropogenic and marine sources (Todd 1980; Stallard and Edmond 1987; Subba Rao 2002; Subba Rao et al. 2014). A dominance of $\mathrm{HCO}_{3}{ }^{-}$favors mineral dissolution (Stumm and Morgan 1996). An abundance of $\mathrm{Cl}^{-}$is a result of leaching from soils and the influence of domestic wastes, salt pans, aquacultural activities, etc. (Todd 1980; Subba Rao et al. 2014). Furthermore, the solubility of $\mathrm{Na}^{+}$and $\mathrm{Cl}^{-}$is high (Hem 1991; Drever 1997). Ferromagnesian minerals and manmade activities (salt pans and aqua-cultural activities) are responsible for higher $\mathrm{Mg}^{2+}$ than $\mathrm{Ca}^{2+}$ in the groundwater (Hem 1991; Drever 1997; Subba Rao et al. 2014). A lower $\mathrm{K}^{+}$indicates its lower geochemical mobility and its absorption on clays (Hem 1991; Drever 1997). Fluoride minerals, agro-chemicals, etc., are the sources of $\mathrm{F}^{-}$in the groundwater (Ayoob and Gupta 2006; Rao et al. 2014).

The $\mathrm{F}^{-}$is plotted against $\mathrm{pH}$ and $\mathrm{HCO}_{3}{ }^{-}$(Figs. 5, 6). The $\mathrm{F}^{-}$shows a significant positive correlation with $\mathrm{pH}$ $(r=0.313, p<0.05)$ and $\mathrm{HCO}_{3}{ }^{-}(r=0.224)$, while it has a negative correlation with $\mathrm{Ca}^{2+}(r=-0.225)$. Furthermore, the $\mathrm{pH}$ has a good positive correlation with $\mathrm{HCO}_{3}{ }^{-}$ $(r=0.224)$, as the infiltrated water reacts with soil $\mathrm{CO}_{2}$, which forms $\mathrm{HCO}_{3}{ }^{-}$, resulting $\mathrm{HCO}_{3}{ }^{-}$and thereby causing a $\mathrm{pH}$ (Berner and Berner 1987). On the other hand, the incongruent dissolution of rock weathering causes a release of $\mathrm{HCO}_{3}{ }^{-}$(Drever 1997). This indicates a prevailing condition of alkalinity (caused by $\mathrm{HCO}_{3}{ }^{-}$only here) in the groundwater, which promotes a mineral dissolution (Stumm and Morgan 1996). An easy accessibility of circulating water caused by rainwater and/or intensive and long-term irrigation practices in the soil and/or weathered zone stimulates the alkalinity more effectively (Wodeyar and Sreenivasan 1996; Subba Rao 2003, 2011; Madhnure et al. 2007). Thus, the alkaline water activates the leaching of $\mathrm{F}^{-}$ bearing minerals (apatite, hornblende, and biotite) present in the host rocks. The chemical relations obviously indicate a greater affinity of $\mathrm{F}^{-}$with $\mathrm{HCO}_{3}{ }^{-}$rather than with $\mathrm{Ca}^{2+}$ (Figs. 2, 6). The residence time of water in the aquifer zone could be high because of the gentle slope and the occurrence of clays in the soil zone as well as in the sub-surface at different depths in the study area. On the other hand, the solubility of $\mathrm{F}^{-}$is low, and its dissolution rate is slow (Nordstrom and Jenne 1977). The solubility of $\mathrm{F}^{-}$increases with the increase of $\mathrm{Na}^{+}$in the groundwater $\left(R^{2}=0.0544\right)$ (Apambire et al. 1997; Gao et al. 2007, 2013; Singaraja et al. 2013; Surya Rao et al. 2015) (Fig. 7).

\section{Triliner diagram}

The principal character of hydro chemical faces can be demonstrated by methods similar to those used in litho faces and geochemical studies-triliner diagram. All water samples from the view point of chemical compounds are derived in three main categories, including $\mathrm{HCO}_{3}{ }^{-}, \mathrm{SO}_{4}{ }^{2-}$, and $\mathrm{Cl}^{-}$types. The piper diagram is used as a tool to identify the water type. The water quality of this is found to be dominated by $\mathrm{Ca}-\mathrm{Mg}-\mathrm{HCO}_{3}$ type in different 


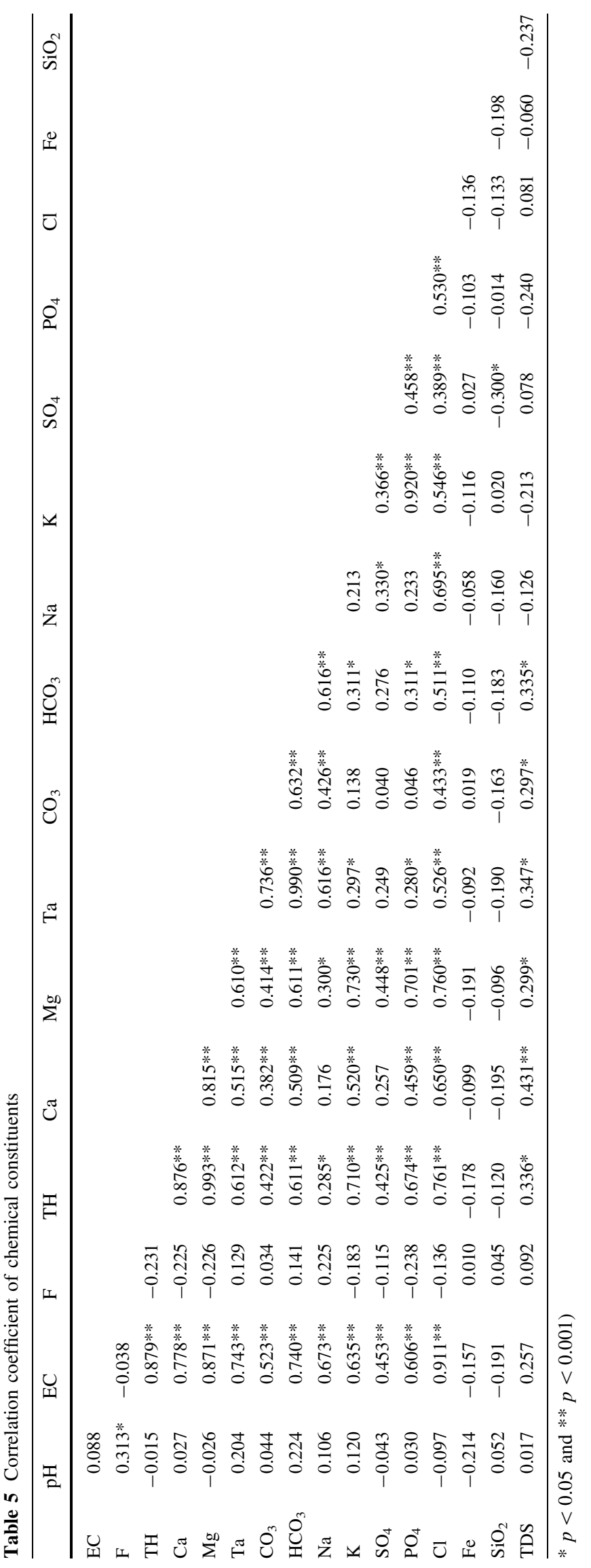




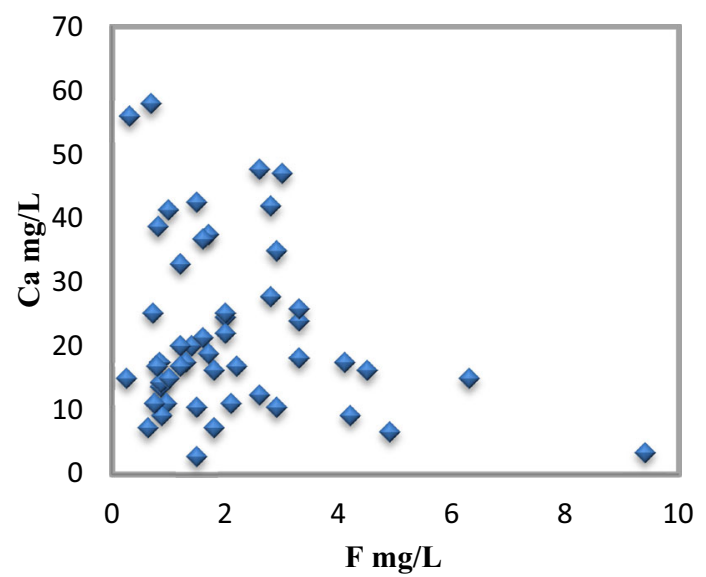

Fig. 2 Scatter plot; measured difference between $\mathrm{F}^{-}$and $\mathrm{Ca}^{2+}$

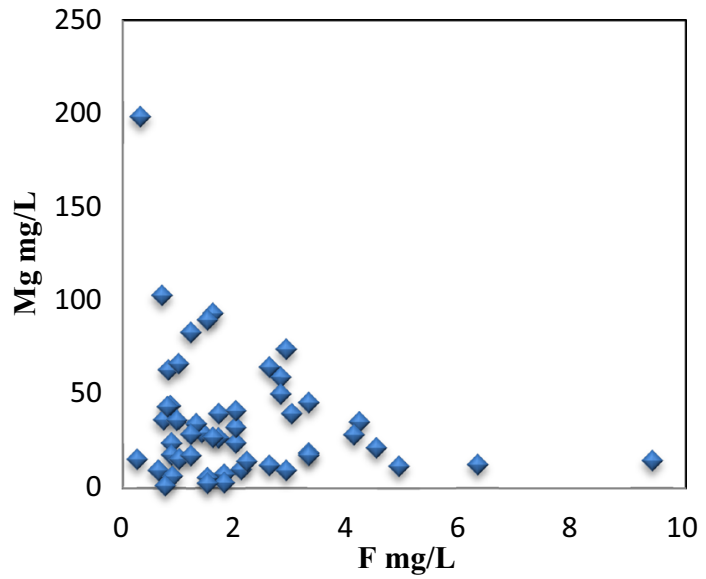

Fig. 3 Scatter plot; measured difference between $\mathrm{F}^{-}$and $\mathrm{Mg}^{2+}$

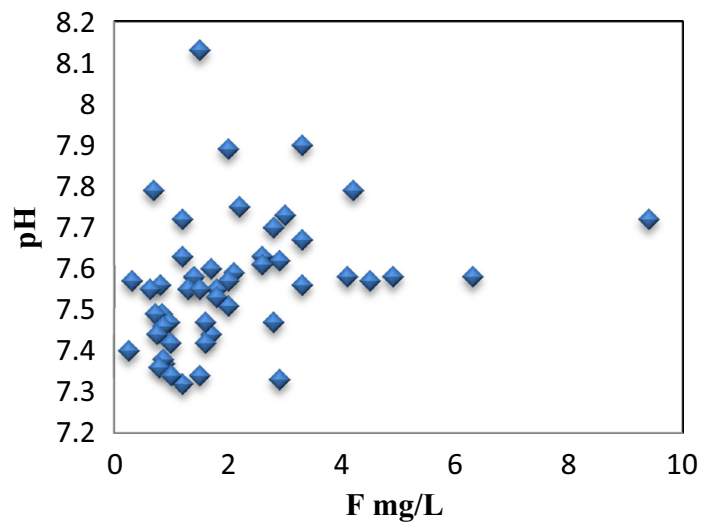

Fig. 4 Scatter plot; measured difference between $\mathrm{F}^{-}$and $\mathrm{pH}$

proportions and combinations. From these experimental samples, 31 types of groundwater facies are evaluated. According to this diagram, the dominant cation is $\mathrm{Mg}^{2+}$ followed by $\mathrm{Na}^{+}$and anion is $\mathrm{HCO}_{3}{ }^{-}$followed by $\mathrm{Cl}^{-}$. Therefore, the chemical character of the water is dominated by $\mathrm{CaHCO}_{3}$ and $\mathrm{NaHCO}_{3}$, and small part of this aquifer is

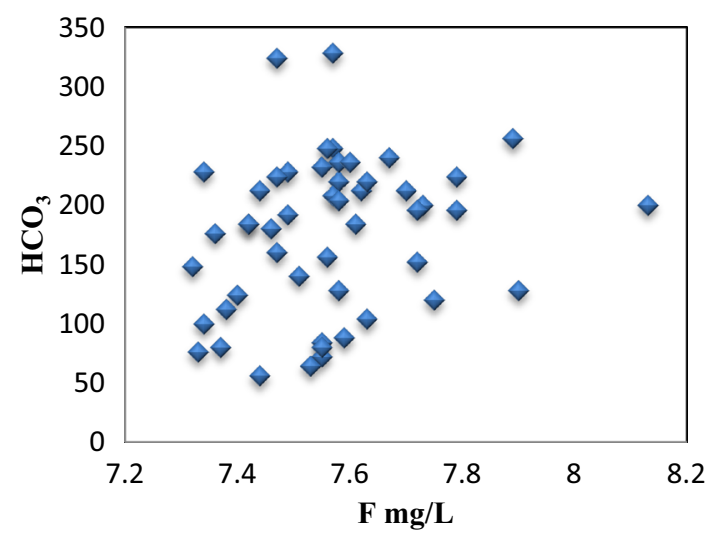

Fig. 5 Scatter plot; measured difference between $\mathrm{F}^{-}$and $\mathrm{HCO}_{3}{ }^{-}$

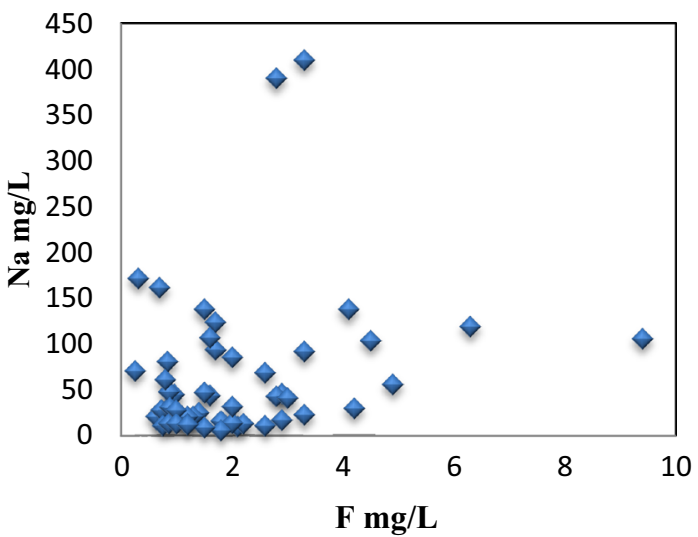

Fig. 6 Scatter plot; measured difference between $\mathrm{F}^{-}$and $\mathrm{Na}^{+}$

dominated by non- carbonated hardness. Based on the plots on the central diamond, the water type is identified in $26 \%$ of the samples in that area which are mixed $\mathrm{Ca}-\mathrm{Na}-\mathrm{HCO}_{3}$ and mixed $\mathrm{Ca}-\mathrm{Mg}-\mathrm{Cl}$ water types and none of the ions are dominant. Identified different groundwater types indicate the variable nature of groundwater chemistry; this suggests that there may be considerable number of different processes influencing the chemistry of groundwater in the study area. From the anionic part, chloride-bicarbonate ratio is a good factor to delineate mixing mechanism of fresh water and saline water from chemical reactions. From the plot, it can be seen that four samples are found to be mixed with saline water and those remaining with low ratios $(88 \%)$ are fresh water in nature (Fig. 8).

\section{Sodium absorption ratio (SAR)}

It is essential to evaluate sodium alkalinity hazard of groundwater because of the presence of excessive amount of sodium participate in ion-exchange reaction with $\mathrm{Ca}^{2+}$ and $\mathrm{Mg}^{+}$and consequence of soil aggregates to disperse and loss of permeability (Turan et al. 2009). The formula for calculating SAR is 
SPATIAL DISTRIBUTION OF FLUORIDE CONCENTRATION

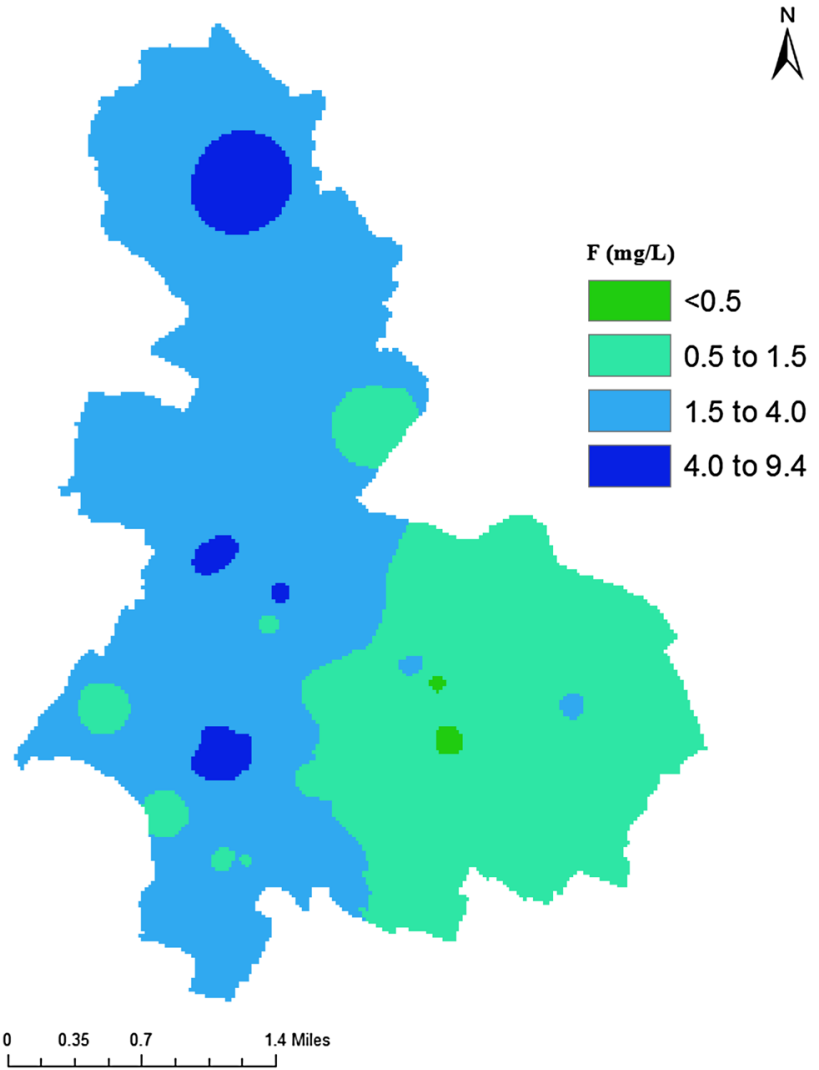

Fig. 7 Spatial distribution of $\mathrm{F}^{-}$concentration of respective study area according to the toxicity class (WHO 2004)

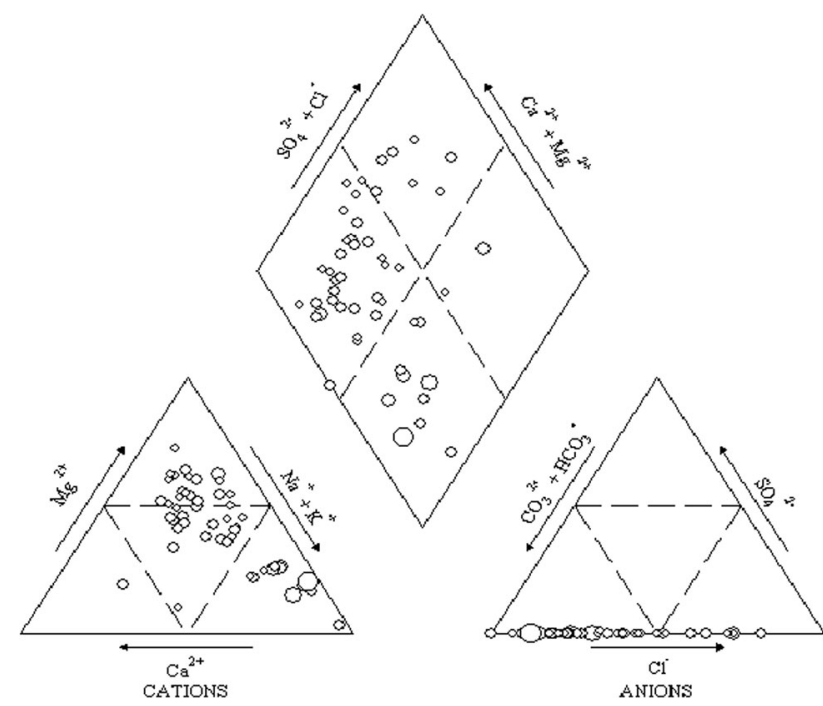

Fig. 8 Piper diagram for samples in the presence of $\mathrm{F}^{-}$

$$
\mathrm{SAR}=\left[\mathrm{Na}^{+}\right] /\left[\left\{\left(\mathrm{Ca}^{++}\right)+\left(\mathrm{Mg}^{++}\right)\right\} / 2\right]^{1 / 2} \text {. }
$$

The calculated values of SAR were observed in the range of $0.350-14.140 \mathrm{meq} / \mathrm{L}$ and mean value of
$2.271 \mathrm{meq} / \mathrm{L}$. $94 \%$ of the studied water samples are excellent for irrigation purpose, and the rest of the samples are good enough for the same purpose (Table 6).

\section{Sodium percent (Na \%)}

Sodium is one of the important factors for water which can illustrate soil permeability and also important for irrigation. It can be determined based on sodium percentage that was calculated using the following formula:

$\mathrm{Na} \%=\frac{(\mathrm{Na}+\mathrm{K}) \times 100}{(\mathrm{Ca}+\mathrm{Mg}+\mathrm{Na}+\mathrm{K})} \mathrm{meq} / \mathrm{L}$

where all ionic concentrations are expressed in meq/L. The result is summarized in Table 7 and indicates that only $2 \%$ of the samples are unsuitable for irrigation purposes, only $18 \%$ are doubtful and permissible for use, and major percent $(48 \%)$ of water are good enough to use for irrigation purposes.

\section{Saturation Index (SI)}

Fluoride concentration in groundwater is often controlled by the solubility of fluorite and calcite among all other geochemical processes (Rafique et al. 2008; Kundu et al. 2011). The solubility limit of fluorite and calcite also provides a natural control on water composition, such that calcium, fluoride, and carbonate activities are interdependent (Kundu et al. 2011). The saturation indices for fluorite and calcite in groundwater samples collected within the study area were calculated and plotted in Fig. 9, which show that the $99.98 \%$ of the total samples were oversaturated with respect to calcite. The $0.02 \%$ sample (sample no S23) sites were oversaturated with respect to fluorite:

$\mathrm{SI}_{\mathrm{F}}=\log \left(a_{\mathrm{Ca}} \times a_{\mathrm{F}}^{2}\right)-\log \left(K_{\text {SPfluorite }}\right)$,

$\mathrm{SI}_{\mathrm{c}}=\log \left(a_{\mathrm{Ca}} \times a_{\mathrm{CO}_{3}}\right)-\log \left(K_{\text {SPcalcite }}\right)$

where $a$ is the activity or mole concentration term and $K_{\text {sp }}$ is the solubility product. $\log K_{\text {sp }}$ values for fluorite and calcite at $25^{\circ} \mathrm{C}$ are $3.45 \times 10^{-11}$ and $4.8 \times 10^{-9}$ (Smyshlyaev and Edeleva 1962).

\section{Principal component analysis (PCA)}

The PCA is a powerful pattern recognition technique that attempts to reduce dimensionality from 17 physicochemical parameters determined in 50 groundwater samples to four principal components (PCs) which have Eigen value greater than 1 and explained $74.21 \%$ variance cumulatively (Table 8). PCA was constructed on this large data set 
Table 6 Water suitability classes according to SAR
Table 7 Water suitability classes according to sodium percent

\begin{tabular}{llll}
\hline SAR & Description & Sample number & \% of samples \\
\hline$<10$ & Excellent & S1-19, S21-25, S27-35, S37-50 & 94 \\
$10-18$ & Good & S20, S26, S36 & 6 \\
$18-26$ & Doubtful & - & - \\
$>26$ & Unsuitable & - & - \\
\hline
\end{tabular}

\begin{tabular}{lllc}
\hline $\mathrm{Na} \%$ & Description & Sample number & \% of samples \\
\hline$<20$ & Excellent & S4, S12, S39, S43, S44, S47, S50 & 14 \\
$20-40$ & Good & S1-3, S7-11, S13-18, S28, S29, S31, S32, S35 & 48 \\
$40-60$ & Permissible & S5, S19, S25, S27, S30, S33, S34, S37, S49 & 18 \\
$60-80$ & Doubtful & S6, S20-24, S26, S38, S48 & 18 \\
$>80$ & Unsuitable & S36 & 2 \\
\hline
\end{tabular}

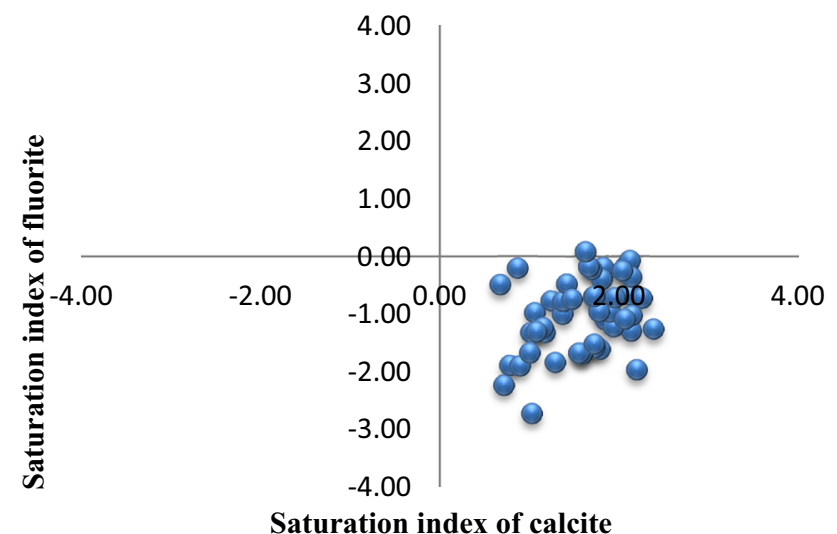

Fig. 9 Saturation index of fluorite and calcite

to illustrate the compositional pattern between examined water system and to identify the factors influencing each one. The first PC which has the highest Eigen value is the highest variance usually represents the most important process controlling the hydro geochemistry.

The first component (F1) accounted for over $32.76 \%$ of the total variance in the data set of groundwater; the physical parameters, major cations, and anions were loaded, which may indicate geological effects. From a macroscopic point of view, all the physicochemical parameters except a few behave similarly. $\mathrm{F} 1$ has high loading with $\mathrm{TH}, \mathrm{EC}, \mathrm{Ca}^{2+}, \mathrm{Mg}^{2+}, \mathrm{K}^{+}, \mathrm{PO}_{4}{ }^{-}, \mathrm{SO}_{4}{ }^{2-}$, and $\mathrm{Cl}^{-}$, less effectively and negatively with $\mathrm{F}^{-}$and $\mathrm{pH}$, indicating a climatic effect. The second component (F2), explaining $19.98 \%$ of the total variance, has strong positive loadings with TA, $\mathrm{CO}_{3}{ }^{2-}, \mathrm{HCO}_{3}{ }^{-}, \mathrm{Na}^{+}, \mathrm{F}^{-}$, and $\mathrm{EC}$. The third component (F3) of PCA shows $12.74 \%$ of the total variation and has positive loading with TDS and $\mathrm{Ca}^{2+}$. The fourth component (F4) of PCA shows that only $8.72 \%$ of the total variation has positive loading with $\mathrm{pH}$ and $\mathrm{SiO}_{2}{ }^{+}$.
Table 8 Factor loadings of experimental variables (17) on significant principal components for groundwater of Simlapal, block

\begin{tabular}{|c|c|c|c|c|}
\hline & \multicolumn{4}{|c|}{ Component } \\
\hline & 1 & 2 & 3 & 4 \\
\hline $\mathrm{pH}$ & -0.081 & 0.349 & -0.055 & 0.603 \\
\hline $\mathrm{EC}$ & 0.768 & 0.554 & 0.238 & -0.028 \\
\hline $\mathrm{F}^{-}$ & -0.406 & 0.517 & -0.123 & 0.264 \\
\hline $\mathrm{TH}$ & 0.871 & 0.203 & 0.415 & 0.026 \\
\hline $\mathrm{Ca}^{2+}$ & 0.701 & 0.134 & 0.563 & -0.006 \\
\hline $\mathrm{Mg}^{2+}$ & 0.881 & 0.210 & 0.364 & 0.033 \\
\hline $\mathrm{TA}$ & 0.347 & 0.790 & 0.378 & 0.031 \\
\hline $\mathrm{CO}_{3}{ }^{2-}$ & 0.159 & 0.617 & 0.426 & -0.089 \\
\hline $\mathrm{HCO}_{3}{ }^{-}$ & 0.364 & 0.774 & 0.343 & 0.055 \\
\hline $\mathrm{Na}^{+}$ & 0.271 & 0.838 & -0.243 & -0.135 \\
\hline $\mathrm{K}^{+}$ & 0.888 & 0.051 & -0.188 & 0.166 \\
\hline $\mathrm{SO}_{4}{ }^{2-}$ & 0.513 & 0.191 & -0.118 & -0.377 \\
\hline $\mathrm{PO}_{4}^{-}$ & 0.895 & 0.025 & -0.251 & 0.070 \\
\hline $\mathrm{Cl}^{-}$ & 0.737 & 0.436 & 0.081 & -0.135 \\
\hline $\mathrm{Fe}^{2+}$ & -0.176 & $-9.130 \mathrm{E}-5$ & -0.122 & -0.653 \\
\hline $\mathrm{SiO}_{2}{ }^{+}$ & -0.032 & -0.217 & -0.196 & 0.629 \\
\hline TDS & -0.060 & 0.111 & 0.892 & -0.052 \\
\hline$\%$ of variability & 32.76 & 19.98 & 12.74 & 8.72 \\
\hline Cumulative variability & 32.76 & 52.75 & 65.49 & 74.21 \\
\hline
\end{tabular}

\section{Fluoride in groundwater}

The association of $\mathrm{F}^{-}$by the use of correlation coefficient with other physicochemical parameters are shown in Table 5. A positive correlation between $\mathrm{F}^{-}$concentration and $\mathrm{pH}$ used to be observed $\left(r=0.313^{*}, p<0.05\right)$ which is consistent with a different study (Vasquez et al. 2006). This can be as a result of the identical ionic radii of $\mathrm{F}^{-}$and $\mathrm{OH}^{-}$, which normally substitute each other inside minerals (Rafique et al. 2008). It was once said that clay minerals are 
capable to keep $\mathrm{F}^{-}$ions on their surfaces; however, at high $\mathrm{pH}, \mathrm{OH}^{-}$ions can displace $\mathrm{F}^{-}$ions, which can be then released to groundwater (Rafique et al. 2008; Sreedevi et al. 2006). This suggests that the groundwater samples of chosen villages of Simlapal have elevated level of $\mathrm{F}^{-}$and $\mathrm{pH}$ (7.32-8.13). These outcomes are consisted with different studies carried out in India (Saxena and Ahmed 2003).

The $\mathrm{F}^{-}$has positive correlation with $\mathrm{HCO}_{3}{ }^{-}$ ( $r=0.141)$. Therefore, an alkaline $\mathrm{pH}$ is favorable for $\mathrm{F}^{-}$ dissolution (Saxena and Ahmed 2003). The identical development was once located in other reviews carried out in distinctive elements of the arena (Gizaw 1996; Rafique et al. 2008). The TDS values have optimistic correlation with $\mathrm{F}^{-}(r=0.092)$. In site $\mathrm{S} 13, \mathrm{~S} 27$, and $\mathrm{S} 38$, the $\mathrm{F}^{-}$ concentration was $>1.5 \mathrm{mg} / \mathrm{L}$, which is related to higher value of TDS (>200 mg/L) (Table 4). The resulted information was consisted with other studies (Sreedevi et al. 2006; Subba 2003).

From the $\mathrm{SI}_{\mathrm{F}}$ value, it has been observed that all the water samples are over saturated with respect to calcite. The over saturation of calcite in water is the indication of availability of calcium in water. High fluoride containing water samples showed low calcium content relative to other; when over saturated, calcium is precipitated as $\mathrm{CaCO}_{3}$ and makes the water under saturated to fluorite. Thus, there is always net balance of fluoride in solution and this prevents precipitation; consequently, it increases the chance of fluoride contamination in water (Kundu et al. 2011). In the present study, negative SI values of fluorite and positive SI values for calcite are obtained from SI, results which are attributed to the mineral richness of that particular area.

The high levels of $\mathrm{F}^{-}(>1.5 \mathrm{mg} / \mathrm{L})$ cause dental and skeletal fluorosis and may harm to kidneys, nerves, and muscles (Ayoob and Gupta 2006; Das et al. 2013; Das and Mondal 2016). The problem of dental and skeletal fluorosis is common in the areas of crystalline basement rocks, particularly those of granitic composition in different parts of the world (Edmunds and Smedley 2005).

\section{Limitations of the study}

Bankura district is drought prone and a very dry area and the water table goes down in winter and summer. All the water samples are collected from the DTW, and thus, the depth variation of $\mathrm{F}^{-}$concentration was not emphasized in this study. Thus, emphasis is only given on the quality of water and source of water in the aquifer whether mixing upwards or not. As this is only single season study, further multiple season studies might more evidently describe the behavior of different chemical constituents including $\mathrm{F}^{-}$.

\section{Conclusion}

A positive correlation between $\mathrm{F}^{-}$concentration and $\mathrm{pH}$ was observed $\left(r=0.313^{*}, p<0.05\right)$ which is consisted with different studies. The $\mathrm{F}^{-}$values have positive correlation with $\mathrm{HCO}_{3}{ }^{-}(r=0.141)$. Therefore, an alkaline $\mathrm{pH}$ is favorable for $\mathrm{F}^{-}$dissolution. The TDS has optimistic correlation with $\mathrm{F}^{-}$ $(r=0.092)$. At sites $\mathrm{S} 13, \mathrm{~S} 27$, and $\mathrm{S} 38$, the $\mathrm{F}^{-}$concentration was $>1.5 \mathrm{mg} / \mathrm{L}$ which is related to higher value of TDS (>200 mg/L). The first component (F1) accounted for over $32.76 \%$ of the total variance in the data set of groundwater; the physical parameters, major cations, and anions were loaded, which may indicate geochemical effects. From a macroscopic point of view, all the physicochemical parameters except a few behave similarly. $\mathrm{F} 1$ values have high loading with $\mathrm{TH}, \mathrm{EC}, \mathrm{Ca}^{2+}, \mathrm{Mg}^{2+}, \mathrm{K}^{+}, \mathrm{PO}_{4}^{-}, \mathrm{SO}_{4}{ }^{2-}$, and $\mathrm{Cl}^{-}$; less effectively and negatively with $\mathrm{F}^{-}$and $\mathrm{pH}$ indicating the climatic effect. The second component (F2), explaining $19.98 \%$ of the total variance, has strong positive loadings with TA, $\mathrm{CO}_{3}{ }^{2-}, \mathrm{HCO}_{3}{ }^{-}, \mathrm{Na}^{+}, \mathrm{F}^{-}$, and EC. The third component (F3) of PCA shows $12.74 \%$ of the total variation and has positive loading with TDS and $\mathrm{Ca}^{2+}$. The fourth component (F4) of PCA shows only $8.72 \%$ of the total variation and has positive loading with $\mathrm{pH}$ and $\mathrm{SiO}_{2}$. In the present study, negative SI values of fluorite and positive SI values for calcite are obtained from SI; the results are attributed to mineral richness of that particular area. According to the piper diagram, water quality is found to be dominated by $\mathrm{Ca}-\mathrm{Mg}-$ $\mathrm{HCO}_{3}$ type in different proportions and combinations. Chemical character of the water is dominated by $\mathrm{CaHCO}_{3}$ and $\mathrm{NaHCO}_{3}$. A small part of this aquifer is dominated by noncarbonated hardness. Based on the plots, the water type is identified in $26 \%$ of samples in that area as mixed $\mathrm{Ca}-\mathrm{Na}-$ $\mathrm{HCO}_{3}$ and mixed $\mathrm{Ca}-\mathrm{Mg}-\mathrm{Cl}$ types and none of the ions are dominant. Finally, water quality in terms of irrigation purposes SAR revealed all the water samples useful. With respect to permeability of sodium, $18 \%$ are permissible thought doubtful and $2 \%$ are unsuitable for irrigation purposes.

Acknowledgments The authors would like to show sincere thanks to the Department of Environmental Science, The University of Burdwan, for providing laboratory facility. The authors are also thankful to Miss Aparna Nayek and Mr. Tapan Babu, Teacher, Laxmisagar Primary School for their kind and sincere help during the sample collection and lastly to Mr. Soumitra Singha Mahapatra for his kind cooperation in every step of sampling in the numerous study.

\section{References}

American Public Health Association (APHA) (1998) Standard methods for the examination of water and wastewater, 20th edn. APHA, Washington DC

Apambire WB, Boyle DR, Michel FA (1997) Geochemistry, genesisand health implications of fluoriferous groundwaters in the upper regions of Ghanna. Environ Geol 33:13-24 
Ayoob S, Gupta AK (2006) Fluoride in drinking water: a review on the status and stress effects. Crit Rev Environ Sci Tech 36:433-487

Berner EK, Berner RA (1987) The global water cycle, geochemistry and environment. Prentice-Hall, New Jersey

Chakrabarti S, Bhattacharya HN (2013) Inferring the hydro-geochemistry of fluoride contamination in Bankura district, West Bengal: a case study. J Geol Soc India 82(4):379-391

Das K, Mondal NK (2016) Dental fluorosis and urinary fluoride concentration as a reflection of fluoride exposure and its impact on IQ level and BMI of children of Laxmisagar, Simlapal Block of Bankura District, W.B., India. Environ Monit Assess 188(4):218

Das K, Dey U, Roy P, Pal KC, Mondal NK (2013) Dental Fluorosis Among Children In Laxmisagar Village, Bankura District, West Bengal, India. Fluoride 46(4):230-233

Drever JI (1997) The geochemistry of natural waters, 3rd edn. Prentice Hall, Englewood 436

Edmunds WM, Smedley PL (2005) Fluoride in natural waters. In: Selinus O (ed) Essentials of medical geology. Elsevier Academic Press, Burlington, pp 301-329

Farooqi A, Masuda H, Firdous N (2007) Toxic fluoride and arsenic contaminated groundwater in the Lahore and Kasur districts, Punjab, Pakistan and possible contaminant sources. J Environ Pollut 145:839-849

Gao X, Wang Y, Li Y, Guo Q (2007) Enrichment of fluoride in groundwater under the impact of saline water intrusion $t$ the salt lake area of Yuncheng basin, Northern China. Environ Geol 53:795-803

Gao XB, Zhang FC, Wang C, Wang YX (2013) Coexistence of high fluoride fresh and saline groundwaters in the Yuncheng Basin, northern China. Proc Earth Planet Sci 7:280-283

Girish G (2003) An integrated hydrogeological study of the muvattupuzha river basin, Kerala, India. Unpublished Thesis, Cochin University of Science and Technology, Cochin, pp 1-271

Gizaw B (1996) The origin of high bicarbonate and fluoride concentration in waters of themain Ethiopian rift valley, East African rift system. J Afr Earth Sci 22:391-402

Hem JD (1991) Study and interpretation of the chemical characteristics of natural water. In: United States Geological Survey professional paper 2254, Scientific Publisher, Jodhpur

Karthikeyan K, Nanthakumar K, Velmurugan P, Tamilarasi S, Lakshmanaperumalsamy P (2010) Prevalence of certain inorganic constituents in groundwater samples of Erode district, Tamilnadu, India, with special emphasis on fluoride, fluorosis and its remedial measures. Environ Monit Assess 160:141-155

Kaz TG, Arain MB, Jamali MK, Jalbani N, Afridi HI, Sarfraz RA, Baig JA, Shah AQ (2009) Assessment of water quality of polluted lake using multivariate statistical techniques: a case study. Ecotoxicol Environ Saf 72:301-309

Kundu N, Panigrahi MK, Tripathy S, Munshy S, Powell MA, Hart BR (2011) Geochemical appraisal of fluoride contamination of groundwater in the Nayagrah District of Orissa, India. Environ Geol 41:451-460

Laluraj CM, Gopinath G, Dineshkumar PK (2005) Groundwater chemistry of shallow aquifers in the coastal zones of Cochin, India. Appl Ecol Environ Res 3(1):133-139

Liu CW, Lin KH, Kuo YM (2003) Application of factor analysis in the assessment of groundwater quality in a blackfoot disease area in Taiwan. Sci Total Environ 313:77-89

Madhnure P, Sirsikar DY, Tiwari AN, Ranjan B, Malpe DB (2007) Occurrence of fluoride in the groundwaters of Pandharkawada area, Yavatmal District, Maharashtra, India. Curr Sci 92:675-679

Maithani PB, Gurjar R, Banerjee R, Balaji BK, Ramachandran S, Singh R (1998) Anomalous fluoride in groundwater from western part of Sirohi district, Rajasthan, and its crippling effects on human health. Curr Sci 74(9):773-777

Meenakshi VK, Garg Kavita, Renuka Anju Malik (2004) Groundwater quality in some villages of Haryana, India: focus on fluoride and fluorosis. J Hazard Mater 106B:85-97

NBSS \& LUP (2016) Bankura District, West Bengal. Soils of Bankura District (West Bengal) For Land Use Planning Regional Centre Calcutta; National Bureau of Soil Survey \& Land Use Planning (Indian Council of Agricultural Research) Nagpur440 033, Maharashtra, India REPORT NO. 491

Nordstrom DK, Jenne EA (1977) Fluoride solubility in selected geothermal waters. Geochim Cosmochim Acta 41:175-188

Rafique T, Naseem S, Bhanger MI, Usmani TH (2008) Fluoride contamination in the groundwater of Mithi sub-district, the Thar Desert, Pakistan. Environ Geol 56:317-326

Rajmohan N, Elango L (2004) Identification and evolution of hydrogeochemical processes in the groundwater environment in a part of Palar and Cheyyar River Basins, southern India. Environ Geol 46:47-61

Rao PN, Rao AD, Bhargav JS, Siva Sankar K, Sudharshan G (2014) Regional appraisal of the fluoride occurrence in groundwaters of Andhra Pradesh. J Geol Soc India 84:483-493

Samal AC, Bhattacharya P, Mallick A, Ali MM, Pyne J, Santra SC (2015) A study to investigate fluoride contamination and fluoride exposure dose assessment in lateritic zones of West Bengal, India. Environ Sci Pollut R 22(8):6220-6229

Saxena VK, Ahmed S (2003) Inferring the chemical parameters for the dissolution of fluoride in groundwater. Environ Geol 43:731-736

Shaji E, Bindu Viju J, Thambi DS (2007) High fluoride in groundwater of Palghat District, Kerala. Curr Sci 92(2):240-245

Singaraja C, Chidambaram S, Anandhan P, Prasanna MV, Thivya C, Thilagavathi R (2013) A study on the status of fluoride ion in groundwater of coastal hard rock aquifers of south India. Arab J Geosci 6:4167-4177

Smyshlyaev SI, Edeleva NP (1962) Determination of the solubility of minerals, I, solubility product of fluorite. Izv Vysshikh Uehebn Zavedenii Khim I Khim Technologiya. V 5

Sreedevi PD, Ahmed S, Made B, Ledoux E, Gandolfi JM (2006) Association of hydrological factors in temporal variations of fluoride concentration in a crystalline aquifer in India. Environ Geol 50:1-11

Stallard RF, Edmond JM (1987) Geochemistry of the Amazon. 3: Weathering chemistry and limits to dissolve inputs. J Geophys Res 92:8292-8302

Stumm W, Morgan JJ (1996) Aquatic chemistry. Wiley-Interscience, New York

Subba R (2003) Groundwater quality: focus on fluoride concentration in rural parts of Guntur districts, Andhra Pradesh, India. Hydrol Sci J 48(5):877-892

Subba Rao N (2002) Geochemistry of groundwater in parts of Guntur District, Andhra Pradesh, India. Environ Geol 41:552-562

Subba Rao N (2003) Groundwater quality-focus on fluoride concentration in rural parts of Guntur District, Andhra Pradesh, India. Hydrol Sci J 48:835-847

Subba Rao N (2011) High-fluoride groundwater. Environ Monit Assess 176:637-645

Subba Rao N, Vidyasagar G, Surya Rao P, Bhanumurthy P (2014) Chemistry and quality of groundwater in a coastal region of Andhra Pradesh, India. Appl Water Sci 1-10. doi:10.1007/ s13201-014-0244-0

Surya Rao P, Subba Rao N, Dinakar A (2015) Fluoride in the groundwater in Etcherla Mandal, Srikakulam District, Andhra Pradesh. J Geosci Res 1:53-59

Tekle-Haimanot R, Melaku Z, Kloos H, Reiman C, Fantaye W, Zerihun L, Bjorvatn K (2006) The geographic distribution of 
fluoride in surface and groundwater in Ethiopia with an emphasis on the Rift Valley. J Sci Total Environ 367:182-190

Thirumalesh BV, Thippeswamy B, Shivakumar P, Banakar Naveenkumar KJ, Krishnappa M (2011) Assessment of chemical compounds for in vitro and in vivo activity against bacterial black spot of mango. Rec Res Sci Technol 3(9):57-61

Todd DK (1980) Groundwater hydrology. Wiley, New York

Turan MA, Elkarim AHA, Taban N, Taban S (2009) Effect of salt stress on growth, stomatal resistance, proline and chlorophyll concentrations on maize plant. Afr J Agric Res 4:893-897
USPHS (1987) Drinking water standards. United States Pubic Health Services Publication, Washington, DC

Vasquez LV, Hernandez JR, Lopez JR, Uribe AS, Mancilla OL (2006) The origin of fluoride in groundwater supply to Hermosillo City, Sonora, Mexico. Environ Geol 51:17-27

WHO (2004) Guidelines for drinking water quality. World Health Organization, Geneva

Wodeyar BK, Sreenivasan G (1996) Occurrence of fluoride in the groundwater and its impact in Peddavankahalla Basin, Bellary District, Karnataka, India—a preliminary study. Curr Sci 70:71-74 